https://doi.org/10.18485/primling.2018.19.3

811.131.1'373.43:004.738.5

811.163.41'373.43:004.738.5

Оригинални научни рад

Примљен: 12.03.2018.

Прихваћен: 21.06.2018.

\author{
Јелена Пухар \\ Универзитет у Београду \\ Филолошки факултет
}

\title{
ОНЛАЈН ОНТОЛОГИЈА ИМАГАКТ КАО СРЕДСТВО ЗА УЧЕЊЕ СТРАНИХ ЈЕЗИКА НА ПРИМЕРУ ИТАЛИЈАНСКОГ И СРПСКОГ ЈЕЗИКА
}

\begin{abstract}
Рад се бави Имагактом, вишејезичном онлајн онтологијом глагола радње. На примерима из италијанског и српског језика приказују се начини на које се Имагакт може користити приликом учења страних језика. Анализирају се Dictionary и Compare, два дела Имагакта посредством којих се могу претраживати глаголи радње, а потом се представљају типови радње италијанског глагола portare у Имагакту и његови српски еквиваленти.
\end{abstract}

Кључне речи: глаголи радње, Имагакт, страни језик, италијански језик, српски језик

\section{1. Увод}

Употреба интернета у свакодневном животу допринела је променама и на пољу образовања, те се поред традиционалних наставних материјала за учење страних језика у настави могу примењивати и савремене технологије, што може допринети већој мотивацији ученика (Чилиберти 2012: 135, 152). Нејшн $(2001: 109,110)$ сматра да примена компјутера може бити нарочито корисна приликом учења лексике јер усмерева пажњу ученика на нове речи, омогућавајући визуализацију њихових значења посредством слика. У овоме раду ћемо, на примерима из италијанског и српског језика, показати како се за учење страних језика може употребљавати Имагакт, вишејезична онлајн онтологија глагола радње доступна на сајту http://magactpp.imagact.it.

Глаголи радње означавају свесну, вољну активност агенса (Мразовић 2009: 69). Они су најбројнији глаголи у говорном језику, те представљају основу семантичке компетенције (Монеља, Панунци 2007, Томазело 2003). Будући да су често полисемични, да различити језици не категоризују радње на исте начине и да се значење једне радње може изразити различитим глаголима, могу представљати потешкоће и у учењу страних језика (Гаљарди 2014: 29).

Прву верзију Имагакта, која је садржала италијанске и енглеске глаголе преузете из италијанских корпуса говорног језика „ЛАБЛИТА”, „ЛИП”, „КЛИПС” и 
британског Националног корпуса, израдили су „ЛАБЛИТА” из Фиренце, Катедра за комуникационе науке Универзитета у Сијени и Институт за компутациону лингвистику „Антонио Цамполи” (Гаљарди 2014: 30). Садашња верзија садржи двадесет језика, међу којима су италијански, енглески, шпански, кинески, португалски, немачки, грчки, дански, јапански, хинди, урду те се, с обзиром на број говорника доступних језика, може рећи да Имагакт може употребљавати три милијарде корисника (Ји et al. 2018: 129). Верзија за српски језик, израђена на Филолошком факултету у Београду, доступна је од 2016. године.

Имагакт не садржи лексикографске дефиниције глагола радње, већ је значење глагола приказано одговарајућим сценама, снимљеним у студију или приказаним помоћу ЗД анимација. Свакој сцени која представља одређени тип радње матерњи говорници сваког језика су приписивали одговарајући глаголе у инфинитиву и бележили су просте реченице којима су описиване сцене.

У овом раду ћемо приказати како се језичке информације које произилазе из Имагакта могу користити приликом учења италијанског и српског језика. Бавићемо се начинима претраживања Имагакта посредством његових делова Dictionary и Compare. На примеру глагола portare, његових типова радње и његових српских еквивалената у Имагакту показаћемо како ова онтологија својим корисницима даје јасан увид у различито категоризовање радњи у двама језицима, чиме ученицима омогућава лакше савладавање значења и употребе глагола радње.

\section{2. Начини претраживања Имагакта}

2.1. Део Имагакта Dictionary представља двојезични сликовни речник који корисник може употребљавати када жели да пронађе како се на циљни језик преводи одређени глагол из изворног језика (Панунци et al. 2014: 1164). Тада бира језик и у поље за претраживање уписује глагол, као што је приказано на Слици 1.

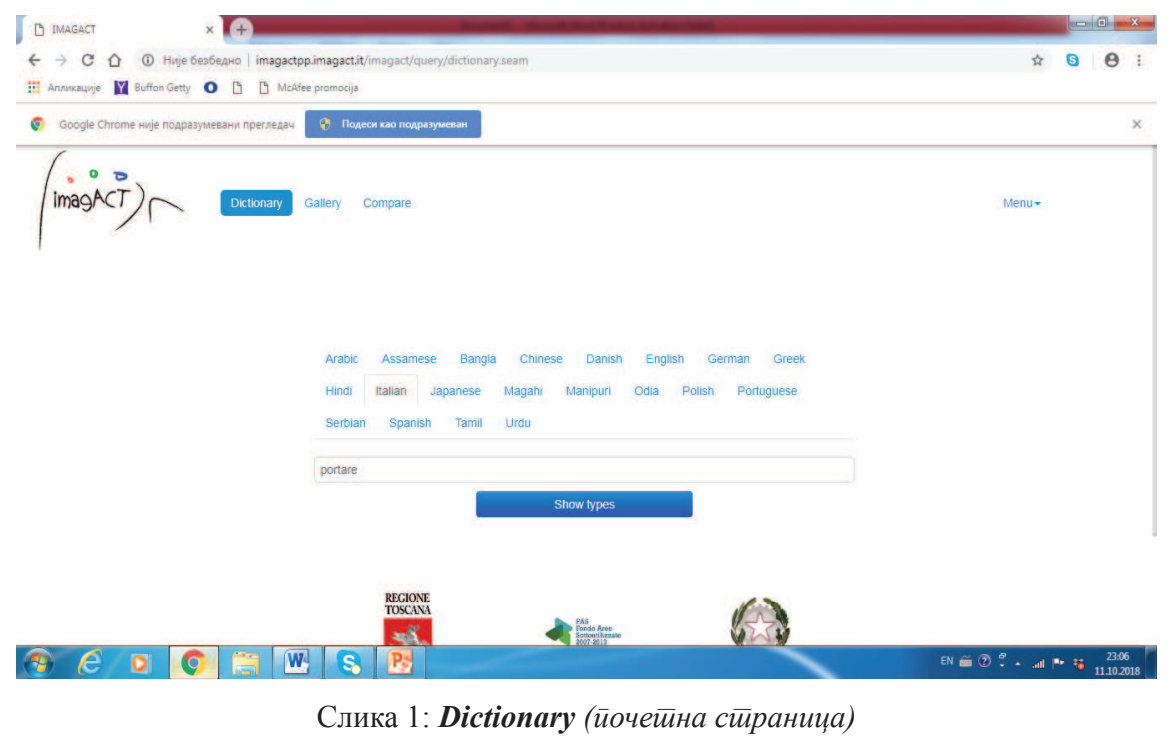

32 
Корисник Имагакта приступа потом страници са анимацијама које приказују различите типове радње одређеног глагола. Може изабрати тип радње и погледати анимацију којом је тип радње приказан. Слика 2 приказује типове радње италијанског глагола portare, чије ћемо српске еквиваленте у Имагакту касније детаљније анализирати.
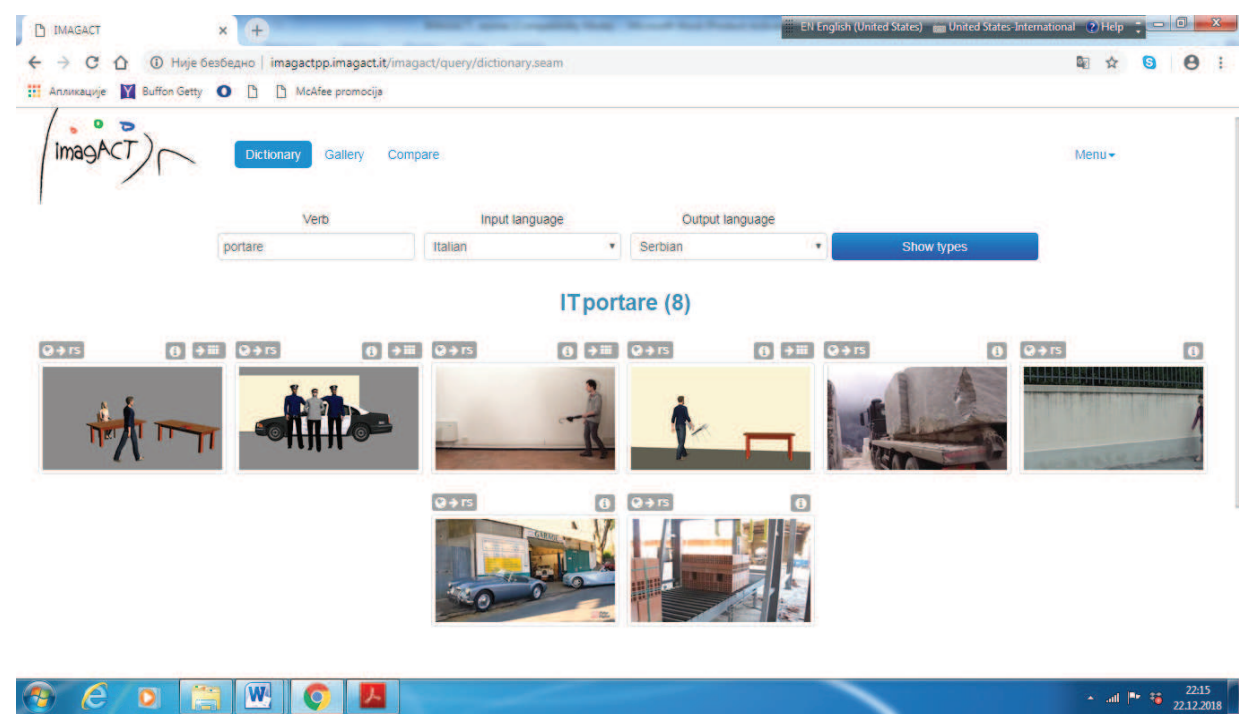

Слика 2: Тийови раgње йлаїола portare

Поред траженог глагола изворног језика и његових еквивалената у циљном језику, Имагакт даје преглед и других глагола изворног и циљног језика који означавају исти тип радње, па се Dictionary може користити и као речник синонима (Слика 3). Тако, на пример, овај део онтологије показује да су у типу радње који означава праћење објекта при кретању, синоними италијанског глагола portare глаголи accompagnare и condurre и да су њихови српски еквиваленти глаголи

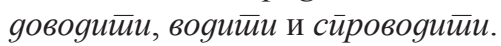




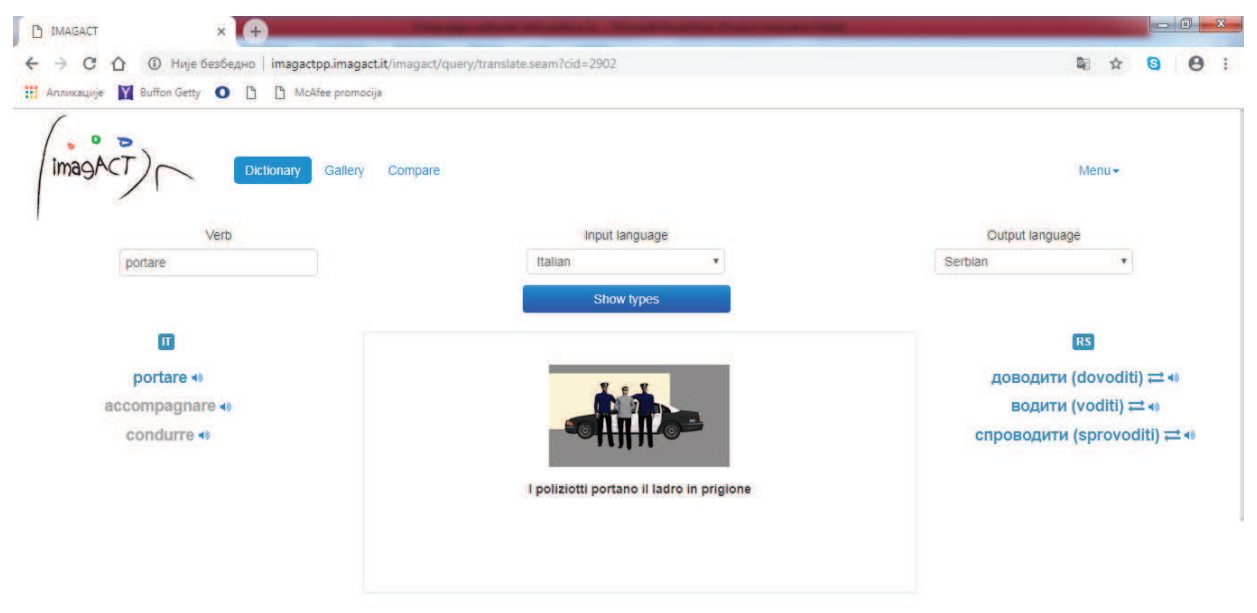

(A) $E$ D $D$ G

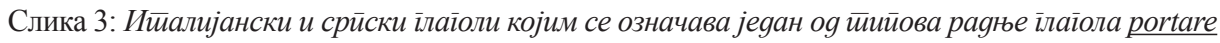

2.2. Део Имагакта Compare омогућава поређење глагола (различитих језика) који се сматрају еквивалентима (Панунци et al. 2014: 1165). Овај део онтологије омогућава кориснику да уочи типове радње за које се могу употребити оба глагола која се пореде (Слика 4). У првој колони се налазе сцене чија се радња означава првим глаголом који се пореди, у трећој колони се приказују сцене које одговарају значењу глагола циљног језика, док се у средишњој колони приказују сцене и типови радње који одговарају обама глаголима који се пореде. На тај начин српски корисник, на пример, може уочити да се глагол portare не може употребљавати за тип радње којим се означава управљање превозним средством, док италијански корисник може увидети да се српски глагол возитии не може користити за тип радње који означава преношење објекта између агенса и бенефактива без употребе превозног средства. Овај део Имагакта италијанском и српском кориснику омогућава такође да увиди да се оба глагола која се пореде (portare и возити $u$ ) могу користити за тип радње којим се означава праћење објекта при кретању превозним средством. 


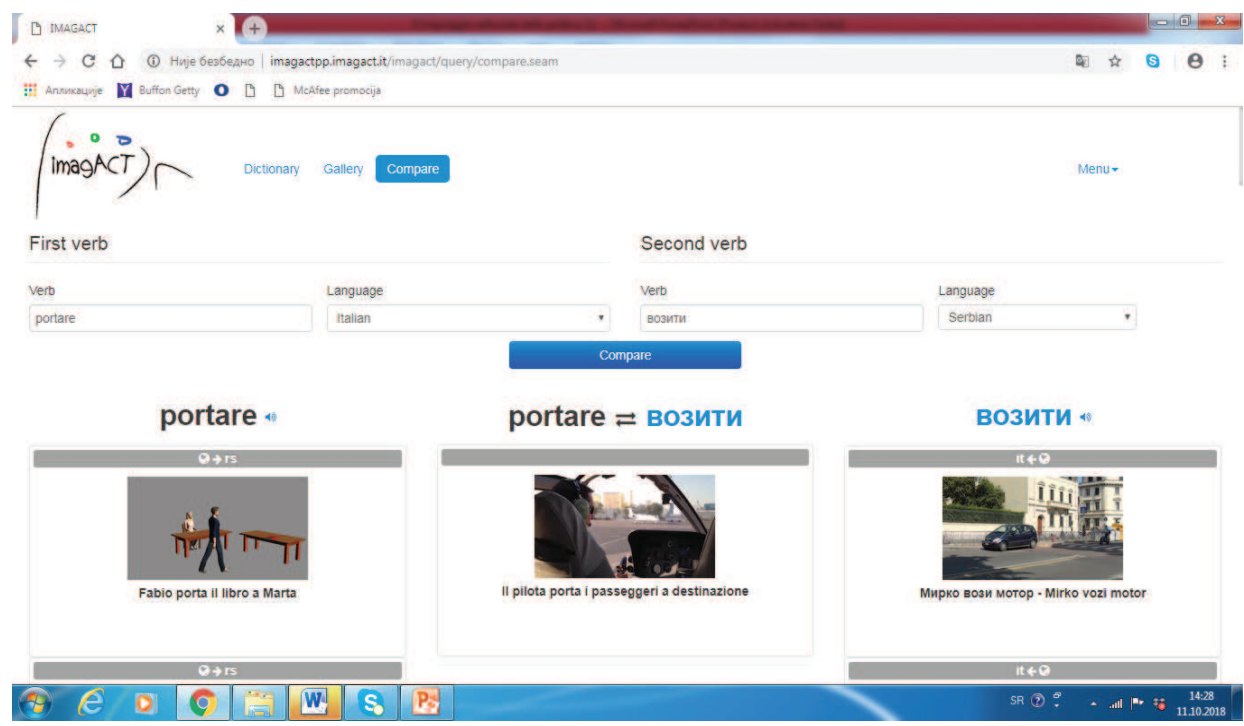

Слика 4: Поређење ииийова раяње їлаїола portare и возитии

Compare омогућава и поређење глагола радње истога језика (Слика 5). Посматрајући сцене које приказују различите типове радње, корисник има увид у разлике у значењу двају глагола. Српски корисник тако може да увиди да су глаголи portare и prendere синоними у типу радње којом се означава померање објекта.

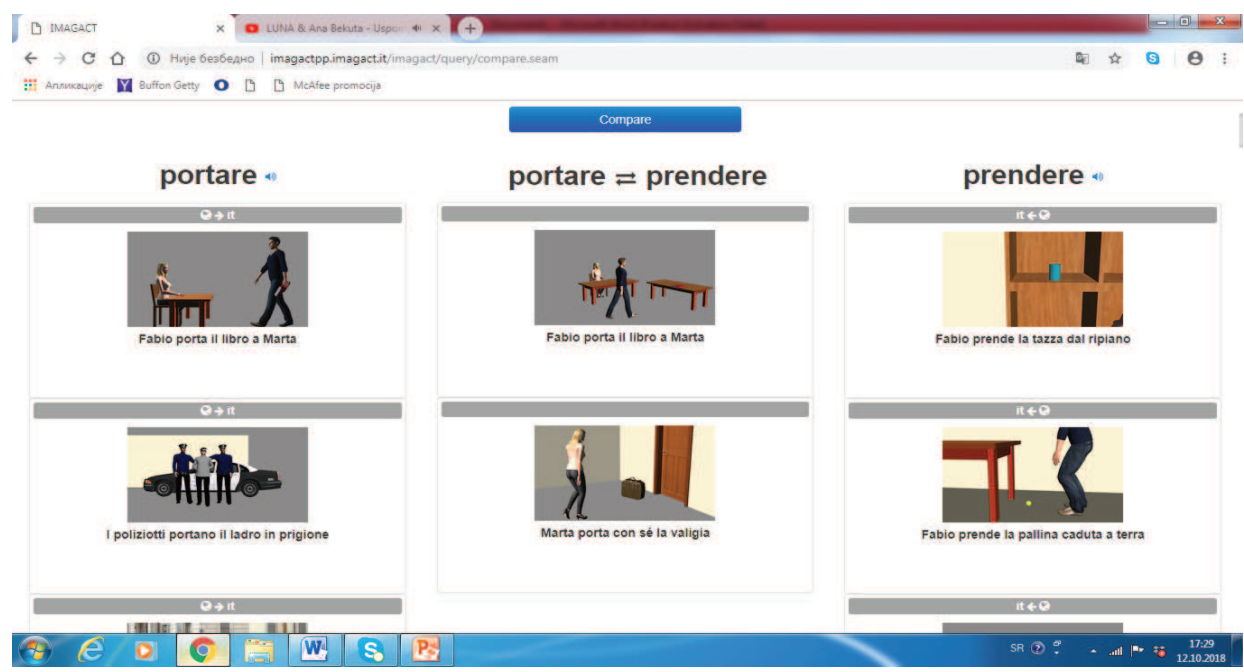

Слика 5: Поређење ииийова раgње іллайола portare u prendere 
2.3. Поред делова Dictionary и Compare, Имагакт садржи и део назван Gallery (Слика 6). Међутим, будући да се у овом раду анализира употреба Имагакта на примерима двају конкретних језика (италијанског и српског) и да у делу Gallery корисници независно од језика сами бирају жељени концепт у галерији прототипских сцена (Панунци et al. 2014: 1167, 1168), у овом раду се нећемо детаљније бавити овим делом онтологије. Ипак сматрамо да треба поменути да Gallery омогућава корисницима да одаберу једну од осам семантичких група у које су разврстани глаголи радње у Имагакту у зависности од начина на који субјекат са обележјем живо [+] категоризује онтолошки простор (Ји et al. 2018: 139).

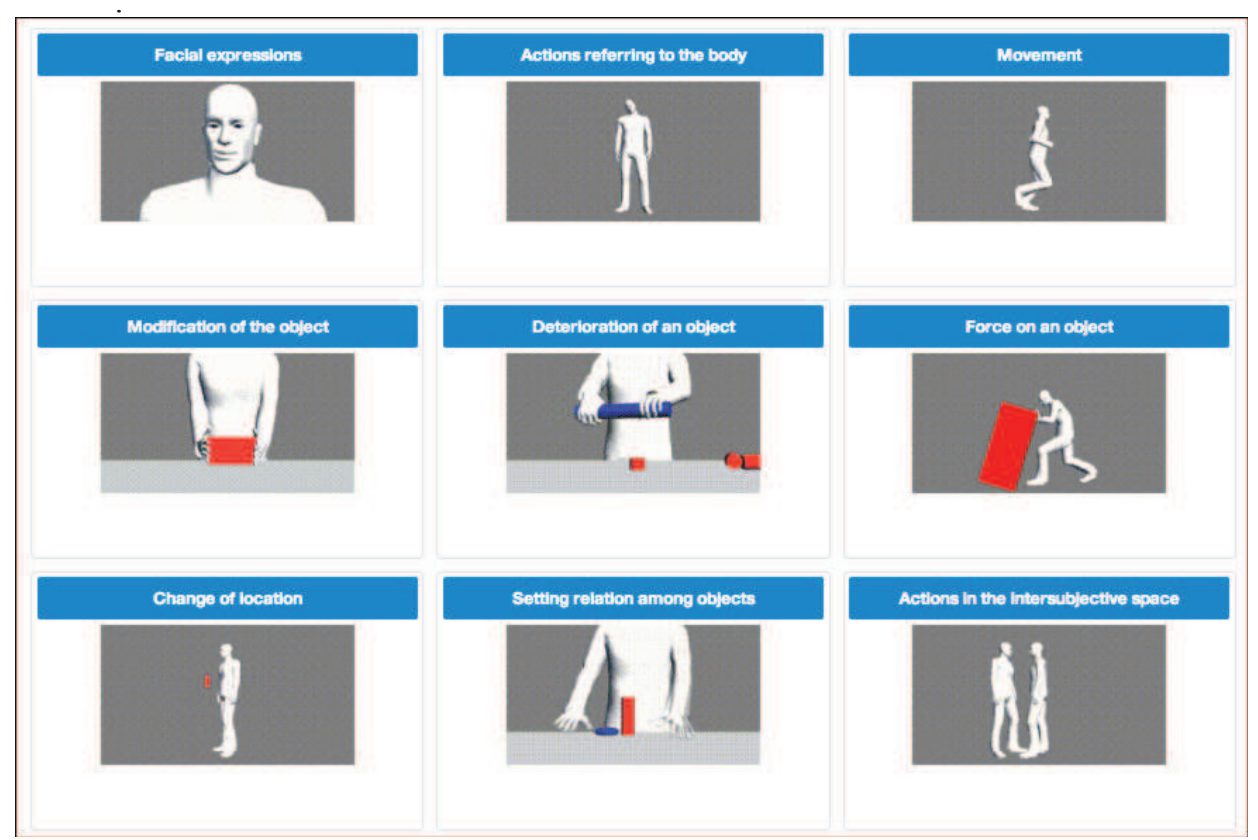

Слика 6: Gallery (иоочейна сиираница)

\section{3. Типови радње глагола portare и његови српски еквиваленти у Имагакту}

У Имагакту је значење глагола portare приказано помоћу сцена које представљају различите типове радње поменутог глагола. За овај глагол је издвојено осам типова радње: преношење објекта у простору, преношење објекта између агенса и бенефактива, поседовање, померање објекта, праћење објекта при кретању, померање објекта у простору (објекат је возило), превоз објекта, преношење објекта (субјекат је инструмент) (Панунци, Монеља 2004: 23). У Табели 1 се налазе српски еквиваленти глагола portare присутни у Имагакту као и слике које представљају сцене којима су ти типови радње приказани. 
Као што се из Табеле 1 може уочити, српски еквиваленти глагола portare

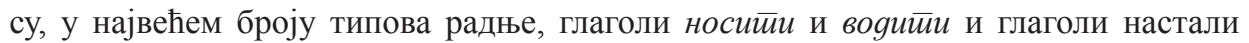
префиксацијом тих глагола. Српски корисник може видети да глагол воgийи није еквивалент глагола portare када је објекат означен неживим појмом. Тако се, на пример, за тип радње којом се означава преношење објекта у простору представљен сценом коју описује реченица Fabio porta la sedia a tavolo не може употребити глагол

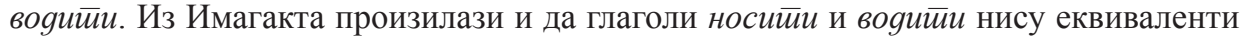
глагола portare када се тип радње односи на померање објекта у простору, при чему је објекат возило. Тада је одговарајући српски еквивалент глагол возитии. На основу поређења типова радњи глагола различитих језика може се закључити да језичке информације произашле из Имагакта потврђује претпоставку да поређење двају језика показује како преко лексике језици на различите начине означавају исте концепте (Јежек 2011: 24).

\begin{tabular}{|c|c|c|}
\hline Тип радње & Сцена & $\begin{array}{c}\text { Српски } \\
\text { еквивалентн(и) }\end{array}$ \\
\hline $\begin{array}{l}\text { Преношење објекта у } \\
\text { простору }\end{array}$ & & $\begin{array}{l}\text { носити, } \\
\text { доносити, } \\
\text { донети, } \\
\text { односити, } \\
\text { однети, } \\
\text { преносити }\end{array}$ \\
\hline $\begin{array}{l}\text { Преношење објекта између } \\
\text { агенса и бенефактива }\end{array}$ & & $\begin{array}{l}\text { доносити, } \\
\text { донети, } \\
\text { односити, } \\
\text { однети }\end{array}$ \\
\hline Поседовање & & носити \\
\hline Померање објекта & & $\begin{array}{l}\text { односити, } \\
\text { однети, } \\
\text { узимати, } \\
\text { узети, } \\
\text { понети }\end{array}$ \\
\hline
\end{tabular}




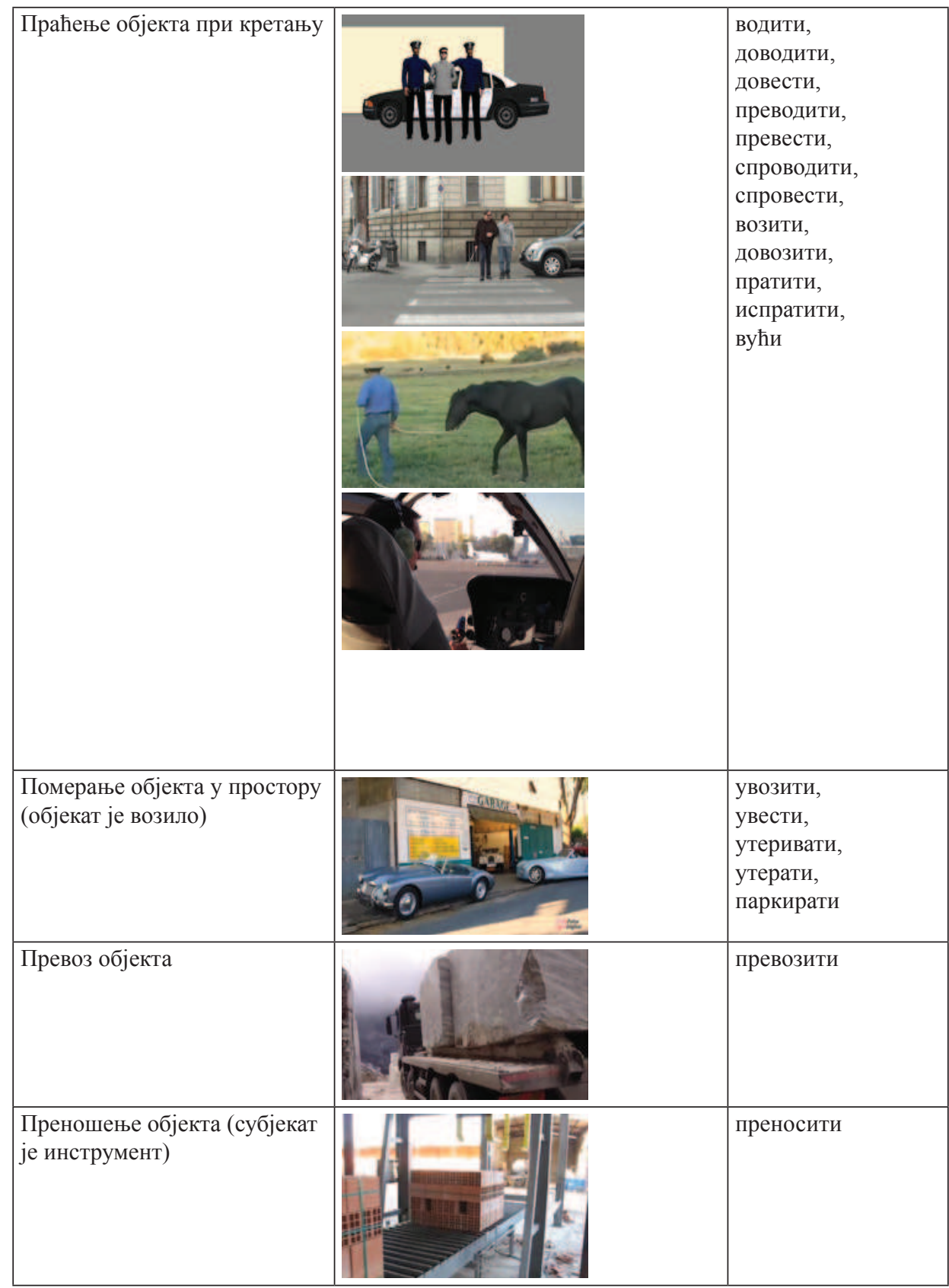

Табела 1: Тийови раяње їлаїола рогtare и њеїови срйски еквивалениии

Поредећи српске еквиваленте глагола portare у онтологији Имагакт и у италијанско-српским речницима Клајн 2010 и Радојичић-Павловић 2006, 
примећујемо да Имагакт поседује већи број преводних еквивалената од наведених двојезичних речника. Поменути речници као еквиваленте глагола portare не бележе

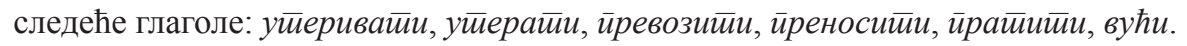

\section{4. Закључак}

На основу анализе италијанских глагола и његових српских еквивалената присутних у Имагакту може се закључити да за многе глаголе Имагакт поседује већи број еквивалената од двојезичних италијанско-српских речника, те стога пружа детаљније информације о лексичкој еквиваленцији у односу на те речнике. Будући да Имагакт садржи и синониме који одговарају типовима радње у изворном и циљном језику, Имагакт се може користити како у првим фазама учења страног језика тако и у каснијим фазама. Од велике користи може бити део Compare, у којем се могу посматрати разлике у типовима радње глагола, при чему се јасно могу увидети семантичке разлике између глагола у изворном и циљном језику. Сматрамо да Имагакт може бити драгоцено средство за учење српског језика јер не показује само семантичке разлике глагола већ, у зависности од типа радње и приказане сцене, и разлике у глаголском виду.

\section{Литература}

Ciliberti, A. (2012). Glottodidattica. Per una cultura dell 'insegnamento linguistico. Roma: Carocci.

Gagliardi, G. (2014). Validazione dell'ontologia dell'azione IMAGACT per lo studio e la diagnosi del Mild Cognitive Impairment. (Doctoral Dissertation). Firenze: Università degli studi di Firenze.

Ježek, E. (2011). Lessico. Bologna: Il Mulino.

Klajn, I. (2010). Italijansko-Srpski rečnik. Beograd: Edicija-Alexandria.

Nation, I.S.P. (2001). Learning vocabulary in another language. Cambridge: Cambridge University Press.

Moneglia, M. and A. Panunzi (2007). Action Predicates and the Ontology of Action across Spoken Language Corpora. The Basic Issue of the SEMACT. In: Proceeding of the International Workshop on the Semantic Representation of Spoken Language (Alcántara Plá, M. \& Declerck, T., eds.), Salamanca: Universidad de Salamanca, 51-58.

Mrazović, P. (2009). Gramatika srpskog jezika za strance. Novi Sad: Izdavačka knjižarnica Zorana Stojanovića, Sremski Karlovci.

Panunzi, A. and M. Moneglia (2004). La Variazione Primaria del verbo nel lessico dei corpora di parlato. In: Atti del Convegno Il Parlato Italiano, volume CD-ROM, C4 (Albano Leoni, F. et al., eds.), Napoli: D'Aura Edizioni, 1-24.

Panunzi et al. (2014). Translating Action Verbs using a Dictionary of Images: the IMAGACT Ontology. In Proceedings of the XVI EURALEX International Congress: The User in Focus (Abel, A. et al., eds.), Bolzano: EURAC Research, 1163-1170.

Radojičić, S., Pavlović, N. (2006). Italijanski rečnik. Beograd: Jasen.

Tomasello, M. (2003). Constructing A Language: A Usage-Based Theory Of Language Acquisition. Cambridge, MA: Harvard University Press.

Yi, P. et al. (2018). IMAGACT4ALL, Una ontologia per immagini dell'azione per 
l'apprendimento del lessico verbale di base delle lingue seconde. In: Usare le lingue seconde. Comunicazione, tecnologia, disabilità, insegnamento (De Meo, A. \& Rasulo, M., eds.), Milano: AitLA, 127-146.

\section{Jelena Puhar \\ USO DELL'ONTOLOGIA IMAGACT NELL'APPRENDIMENTO DELLA LINGUA ITALIANA E SERBA COME LS}

Riassunto: I verbi di azione sono i verbi più numerosi nella lingua parlata (Moneglia, Panunzi: 2007). Essendo polisemici, possono creare problemi per apprendenti di lingue straniere. Lo scopo del presente contributo è quello di presentare l'ontologia interlinguistica Imagact, nella quale sono identificati i tipi di azione dei verbi di azione in venti lingue. La nostra attenzione viene focalizzata sull'uso di Imagact nell'apprendimento della lingua italiana e serba. In questo lavoro viene illustrato l'utilizzo delle due sezioni di Imagact Dictionary e Compare. Inoltre, vengono analizzati i tipi azionali del verbo portare e i suoi traducenti serbi in Imagact.

Parole chiave: verbi di azione, Imagact, lingua straniera, italiano, serbo 